\title{
Check-list of Vertebrates in the "Tenuta dei Massimi" nature reserve (Rome, central Italy) with some remarks on local conservation priorities
}

\section{Corrado Battisti}

Provincia di Roma, Servizio Aree protette, Parchi regionali, Via Tiburtina 691, 00159 Roma, Italia.

E-mail: c.battisti@provincia.roma.it

\begin{abstract}
We reported a complete check-list of Vertebrates for the "Tenuta dei Massimi" nature reserve, a protected area well representing a remnant agro-forest heterogeneous mosaic landscape of the "Campagna Romana". Data were obtained from a large original and bibliographic data-set on a large time-span (1991-2012). This reserve represents an area with a high value of species richness when compared to the surrounding metropolitan areas, also including a large number of species of conservation concern at different scales. We obtained evidences for the occurrence of 141 species (one fish, six amphibians, 12 reptiles, 101 birds, 21 mammals). Among them, some species are of conservation concern at European, regional or local scale. Further research should be focused on a set of fragmentationsensitive species to verify the long-term viability of their local small populations [e.g. Hyla intermedia Boulenger, 1882, Bufo lineatus Ninni, 1879, Muscardinus avellanarius (Linnaeus, 1758), Sorex samniticus Altobello, 1926)].
\end{abstract}

Riassunto - Check-list dei Vertebrati nella riserva naturale "Tenuta dei Massimi" (Roma, Italia centrale) con alcune note conservazionistiche a scala locale.

In questo lavoro viene riportata una check-list dei Vertebrati noti per la riserva naturale "Tenuta dei Massimi" (Roma, Italia centrale), un'area protetta comprendente un mosaico agro-forestale eterogeneo rappresentativo della "Campagna Romana". I dati sono stati raccolti sia in forma originale sia attraverso una revisione bibliografica su un ampio periodo temporale (1991-2012). La riserva rappresenta un sito naturalistico con un'alta ricchezza di specie, se comparato a zone metropolitane limitrofe (141 specie; pesci: 1, anfibi: 6 , rettili: 12, uccelli: 101, mammiferi: 21). Tra queste alcune sono di interesse conservazionistico a scala europea, nazionale e locale. Sono necessarie ulteriori ricerche focalizzate su un set di specie sensibili alla frammentazione per verificare la vitalità a lungo termine delle relative popolazioni [Hyla intermedia Boulenger, 1882, Bufo lineatus Ninni, 1879, Muscardinus avellanarius (Linnaeus, 1758), Sorex samniticus Altobello, 1926].

Key-words: remnant landscape, urbanization, sink populations, relaxation faunas, fragmentation-sensitive species.

\section{INTRODUCTION}

The "Campagna Romana" surrounding Rome (central Italy) is a landscape with a high historical, ecological and conservation value (e.g., Nibby, 1848; Rotondi, 1962; Celesti Grapow \& Fanelli, 1993). Especially in the last
Century, a large number of human-induced disturbances, as land use changes, land reclamation, road building and urbanization, affected the main natural and semi-natural habitat types (oak woods, wetlands and open uncultivated lands) occurring in this historical human-transformed landscape (Celesti Grapow \& Fanelli, 1993). Consequently, the remnant un-transformed habitat fragments have been progressively embedded in an anthropised landscape matrix where progressive extinctions for isolation of many sensitive animal and plant species occurred, with consequent species turnovers in biological communities ("relaxation faunas"; see Gippoliti \& Amori, 2006 for a case study in Rome).

The role of remnant green areas in urbanized landscapes has been highlighted with original research, also carried out in Rome (Sorace, 2001). Recently, many of the natural and semi-natural remnant mosaics occurring in Rome metropolitan area have been included in a network of regional nature reserves where land use change is stopped or limited with positive implications in local conservation of many autochthonous species and communities (Carbone \& Frassineti, 2001; Battisti \& Gippoliti, 2004).

In nature reserve management is crucial to obtain information and assess the value of biodiversity in a study area, e.g. starting from taxonomic checklists (Sutherland, 2000). Therefore, a large research effort aimed to increase the faunal knowledge of these protected areas of Rome has been carried out since the park management plans have been promoted (Bologna et al., 2001, Sarrocco et al., 2002). Especially for Vertebrates, in the last decades many further data on the species occurrences have been obtained thanks to an increased field sampling effort of researchers, volunteers, park managers and atlas projects (e.g., Bologna et al., 2000; 2003; 2007; Amori et al., 2009; Brunelli et al., 2011; F. Fraticelli, unpublished data). Nevertheless, although many research have been carried out in the nature reserves located in Rome metropolitan area, general checklists for all classes of Vertebrates are still scanty (e.g. Crucitti et al., 2013). 
In this work we reported a complete check-list of fauna at Vertebrates for a protected area well representing a remnant habitat mosaic of the "Campagna Romana" landscape ("Tenuta dei Massimi" nature reserve). This check-list has been obtained from a large data-set provided by a wide number of volunteers and researchers spanning two decades. In this work we also provided more specific information on the status of single species at local scale useful for future strategies and actions promoted by the Park Agency managing this area.

\section{MATERIALS AND METHODS}

The "Tenuta dei Massimi" nature reserve (TMNR) is located in the Western suburban area of Rome (central Italy; $41^{\circ} 50^{\prime}$ Lat $\mathrm{N}, 12^{\circ} 23^{\prime}$ Long E; Tav. IGMI 149 I SE "Roma Ovest"). This reserve is 774 ha wide and include a landscape mosaic mainly composed by cultivated areas $(56 \%)$ and oak wood patches $(18 \%$; ranging from 0.1 to about 20 ha in size) belonging to private estates and public lands (Tenuta della Torretta Massimi, T. della Pisana, T. della Brava, T. Somaini, Bosco dell'Infernaccio). In the neighbouring there are other protected areas ("Valle dei Casali" nature reserve, "Acquafredda" nature reserve). Oak wood patches belong to the following plant associations (Fanelli \& Bianco, 2007): Mediterranean forests with Quercus suber dominant (Citiso villosi-Quercetum suberis Testi, Lucattini et Pignatti 1994), sub-mediterranean plain woods with $Q$. cerris and $Q$. frainetto dominants (Mespilo germanicaeQuercetum frainetto Biondi, Gigante, Pignattelli et Venanzoni 2001), hilly woods with $Q$. cerris, $Q$. frainetto and Q. suber (Quercetum frainetto-suberis Blasi, Filesi, Frattini, Stanisci 1997). Reed beds with Arundo pliniana (Arundinetum plinianae Biondi, Brugiapaglia, Allegrezza et Ballelli 1992), anthropogenic hilly uncultivated lands (Vulpio-Dasypiretum Fanelli 1998 and Diplotaxio tenuifolii-Agropyretum repentis Philippi in Th. Muller et Ballelli 1992) also occur in the landscape mosaic (Fanelli \& Bianco, 2007).

Some small streams with hygrophilous vegetation (Salix sp., Populus sp., Arundo donax) are present in the study area (Fosso della Magliana, F. della Maglianella, F. dei Mattei, F. di Brava, F. di Bravetta; Fanelli \& Bianco, 2007). Further details on the local climate (Colle del Sole meteorological station) are in Montinaro \& Cancellieri (2002). Data on flora and vegetation are in Anzalone (1986), Fanelli \& Celesti Grapow (1994), Testi \& Lucattini (1994), Celesti Grapow (1995), Blasi (2001), Fanelli (2002), Montinaro \& Cancellieri (2002). Data on geology and soil types are available in Bellotti et al. (1993), Marra \& Rosa (1995), Downgiallo et al. (1997), Ventriglia (2002) and Arnoldus-Huyzendveld (2003). For a local historical arrangement, see Venditti (1992).

\section{METHODS}

We sampled and cumulated all the original information (field notes), bibliographic references and atlas data-set on Vertebrates species occurring in TMNR (and immediately surrounding areas, with a buffer about 1-km wide) from 1991 and 2012, obtaining a check-list for each systematic class (Pisces, Amphibia, Reptilia, Aves, Mammalia).

Data from literature were obtained from the following bibliographic sources (in chronological order): Cignini \& Zapparoli, 1992; Buscemi et al., 1995; Borlenghi, 1996; Cignini \& Zapparoli, 1996; Battisti et al., 1998a; Battisti et al., 1998b; Salvati \& Manganaro, 1999; Battisti, 2001; Bologna et al., 2001; Bologna et al., 2003; Montinaro \& Cancellieri, 2002; Sarrocco et al., 2002; Battisti 2003; Castaldi \& Guerrieri, 2003; De Giacomo et al., 2003; Panuccio \& Canale, 2003; Battisti \& Zocchi, 2004; Volpes et al., 2004; Zapparoli et al., 2004; Zocchi \& Battisti, 2004; Zocchi et al., 2004; Panuccio, 2005; Pitzalis et al., 2005; Celauro \& Battisti, 2006; Amori et al., 2009; Castaldi \& Guerrieri, 2009; Battisti, 2011; Borlenghi, 2013. For birds, we also obtained original information by unpublished sources and thematic mailing lists (GroB!, SROPU, wintering atlas project of Rome, regional mammal atlas, Strix aluco project - Ente Romanatura).

Many other local data on small mammals has been also obtained thanks to Tyto alba pellets collected in some sites of TMNR (Buscemi et al., 1995; Volpes et al., 2004; Celauro \& Battisti, 2006).

We also critically compared data obtained for TMNR with the occurrences in the neighbouring areas $(10 \times 10$ $\mathrm{km}$ grid unit from regional and provincial atlases: Bologna et al., 2000; Bologna et al., 2007; Amori et al., 2009; Brunelli et al. 2011).

We reported for each species their conservation status at European (birds: 79/409/CEE and 147/2009/CE "Bird" Directives; Vertebrates species excluding birds: 92/43/CEE "Habitat" directive) and national level (Bulgarini et al., 1998; LIPU \& WWF, 1999; Calvario et al., 2008). For birds we reported their local phenology (Brunelli \& Fraticelli, 2010), highlighting their breeding in TMNR.

We followed the taxonomic nomenclature proposed, for Pisces by Kottelat \& Freyhof (2007), for Amphibia by Lanza et al. (2007), for Reptilia by Corti et al. (2010), for Aves by AERC TAC (2003; see also Fracasso et al., 2009 and Battisti \& Zapparoli, 2011, for the domestic form of Columba livia J.F.Gmelin, 1789) and, for Mammalia, by Boitani et al. (2003) and Amori et al. (2008).

\section{RESULTS}

Pisces. We obtained evidences only for introduced individuals of a species, Gambusia hoolbrooki (Girard, 1859; Ciprinodontiformes, Poeciliidae), sampled in a fountain near Torretta Massimi.

Amphibia. We obtained evidences for six species of amphibians occurring in small ephemeral or stable ponds of TMNR (Tab. 1). Among them, four species results of conservation concern.

Reptilia. For reptiles, we obtained evidences for 12 species (six of conservation concern; Tab. 1). 
Tab. 1 - Check list of amphibians (Amphibia) and reptiles (Reptilia) occurring in the "Tenuta dei Massimi" nature reserve (Rome, central Italy). "Habitat" Dir.: the number of Annex (II, IV) of "Habitat" 92/43/ CEE Directive is reported (Sindaco et al., 2006; Calvario et al., 2008); red list: inclusion in IUCN or Italian Red lists is reported (Bulgarini et al., 1998: DD: data deficient). Nomenclature by Lanza et al. (2007) for amphibians and Corti et al. (2010) for reptiles.

\begin{tabular}{|c|c|c|}
\hline Order/FAMILY/species & $\begin{array}{l}\text { "Habitat" } \\
\text { Dir. }\end{array}$ & $\begin{array}{l}\text { Italian } \\
\text { red list }\end{array}$ \\
\hline \multicolumn{3}{|l|}{ AMPHIBIA } \\
\hline \multicolumn{3}{|l|}{ Caudata } \\
\hline \multicolumn{3}{|l|}{ SALAMANDRIDAE } \\
\hline \multicolumn{3}{|l|}{ Lissotriton vulgaris (Linnaeus, 1758) } \\
\hline Triturus carnifex (Laurenti, 1768) & II, IV & \\
\hline \multicolumn{3}{|l|}{ Anura } \\
\hline \multicolumn{3}{|l|}{ BUFONIDAE } \\
\hline \multicolumn{3}{|l|}{ Bufo bufo (Linnaeus, 1758) } \\
\hline Bufo balearicus Stock et al., 2008 & IV & \\
\hline \multicolumn{3}{|l|}{ HYLIDAE } \\
\hline Hyla intermedia Boulenger, 1882 & IV & DD \\
\hline \multicolumn{3}{|l|}{ RANIDAE } \\
\hline $\begin{array}{l}\text { Phelophylax bergeri (Günter, 1985) } \\
\text { complex }\end{array}$ & IV & \\
\hline \multicolumn{3}{|l|}{ REPTILIA } \\
\hline \multicolumn{3}{|l|}{ Squamata } \\
\hline \multicolumn{3}{|l|}{ GEKKONIDAE } \\
\hline \multicolumn{3}{|l|}{$\begin{array}{l}\text { Hemidactylus turcicus } \\
\text { (Linnaeus, 1758) }\end{array}$} \\
\hline \multicolumn{3}{|l|}{$\begin{array}{l}\text { Tarentola mauritanica (Linnaeus, } \\
\text { 1758) }\end{array}$} \\
\hline \multicolumn{3}{|l|}{ SCINCIDAE } \\
\hline \multicolumn{3}{|l|}{ Chalcides chalcides (Linnaeus,1758) } \\
\hline \multicolumn{3}{|l|}{ ANGUIDAE } \\
\hline \multicolumn{3}{|l|}{ Anguis fragilis s.l. Linnaeus, 1758} \\
\hline \multicolumn{3}{|l|}{ LACERTIDAE } \\
\hline Lacerta bilineata Daudin, 1802 & IV & \\
\hline Podarcis muralis (Laurenti, 1768) & IV & \\
\hline $\begin{array}{l}\text { Podarcis siculus (Rafinesque- } \\
\text { Schmaltz, 1810) }\end{array}$ & IV & \\
\hline \multicolumn{3}{|l|}{ Serpentes } \\
\hline \multicolumn{3}{|l|}{ COLUBRIDAE } \\
\hline $\begin{array}{l}\text { Hierophis viridiflavus (Lacépède, } \\
\text { 1789) }\end{array}$ & IV & \\
\hline Natrix natrix (Linnaeus, 1758) & & \\
\hline Natrix tessellata (Laurenti, 1868) & IV & \\
\hline Zamenis longissimus (Laurenti, 1768) & IV & \\
\hline Vipera aspis (Linnaeus, 1758) & & \\
\hline
\end{tabular}

Aves. In the TMNR we obtained cumulative data for 101 bird species (among them 63 are breeding or probably breeding species). Three species are allochtonous [Phasianus colchicus Linnaeus, 1758, Psittacula krameri (Scopoli, 1769), Myiopsitta monachus (Boddaert, 1783)] and one is represented by feral domesticated individuals (Columba livia J.F. Gmelin, 1789 forma domestica; Tab. 2). Twenty-seven species are included in 79/409/CEE and 147/2009/CE 'Birds' Directive and/or are species of conservation concern at national scale (Italian red list; LIPU and WWF, 1999).

Other bird species has been observed in the surrounding areas (e.g., Magliana vecchia, Colle del Sole, Muratella) and probably may occasionally occur in TMNR. They are all migrants (wintering or vagrants): Anas crecca Linnaeus, 1758, Egretta garzetta (Linnaeus, 1766), Casmerodius albus (Linnaeus, 1758), Platalea leucorodia Linnaeus, 1758, Turdus pilaris Linnaeus, 1758, or also probably breeding in surrounding patchy reed beds (e.g., along the Tiber valley; Benassi et al. 2009) as Acrocephalus scirpaceus (Hermann, 1804), Acrocephalus arundinaceus (Linnaeus, 1758) or in shrub habitats as Sylvia communis Latham, 1787 (Brunelli et al., 2011; A. Cardillo, M. Cento, S. Hueting, F. Fraticelli, unpublished data). Among the alien species, Acridotheres tristis (Linnaeus, 1758) has been observed in the neighbouring suburban areas (Cignini and Zapparoli, 1996; M. Pitzalis, unpublished data).

Mammalia. - Among mammals, we obtained cumulative data for 21 species. Among them, four species of bats and one recently introduced rodent species: Myocastor coypus (Molina, 1782). Seven species are of conservation concern (Tab. 3).

\section{DISCUSSION}

The TMNR represents a remnant agroforest heterogeneous landscape with a high value of species richness when compared to the surrounding metropolitan area, including a large number of species of conservation concern at multiple scale.

Among fishes, no one sampling were carried out in larger streams of TMNR and, although the water quality is very low in the larger ones (e.g., Fosso della Magliana), is probable that some species may occur near the confluence of the Tiber river (about $1 \mathrm{~km}$ from the Southern edge of the TMNR). The only species observed, the mosquitofish Gambusia holbrooki (Girard, 1859), largely occurring in the Campagna Romana landscape at least from Sixty's (e.g., Valenti, 1964; Stella et al., 1984), has been introduced for sanitary purpose (Ronchetti, 1968). Further research are requested for this group.

Amphibians are well represented in TMNR. All the species result very localized and, probably, locally declining for isolation of their populations (Bologna et al., 2003). Moreover the species are vulnerable by a large set for human-induced threats: we occasionally have observed a large number of individuals crossing roads in the reserve and their surrounding: e.g., in Bufo bufo (Linnaeus, 1758) and Bufo lineatus Ninni, 1879, so being vulnerable to road killing. 
Among reptiles, further research are necessary to verify the local presence of Testudo hermanni (Gmelin, 1789) and Emys orbicularis (Linnaeus, 1758), both occurring in the surrounding areas (Bologna et $a l ., 2003)$. The only records of the first species was an anatomic remains, probably belonging to an introduced individual (near via della Pisana). Further research focused on snakes should be carried out: some of species belonging to this group occur in the neighbouring areas: e.g., Coronella girondica (Daudin, 1803) has been observed near TMNR (Vigna Taglianti in Bologna et al., 2003; see also Bologna et al., 2000).

Among birds, we obtained data for a large number of species cumulated over a large time span. Breeding birds represent an important component (about $64 \%$ in species number). Sarrocco \& Sorace (2011), estimated for TMNR a mean species richness of 57 breeding species (range at regional level: 37-83; index of ornithological value $=10.2$; range: $3.6-44.3$ ), so showing an intermediate value when compared to the system of protected areas of Latium. A large set of species is included among the lists of conservation concern at European and national scale (LIPU \& WWF, 1999; Calvario et al., 2008; see also Calvario et al., 2011).

At single species level, the study area host a small breeding colony of Milvus migrans (Boddaert, 1783), the only one inside in the suburban area of Rome (Borlenghi, 1996; Battisti \& Cignini, 1997; Battisti et al., 2001; Battisti et al., 2003; Battisti \& Zocchi, 2004; Zocchi \& Battisti, 2004; Zocchi et al., 2004). This colony utilize the surrounding areas (Malagrotta, Tiber river) as trophic site (De Giacomo et al., 2003, Panuccio \& Canale, 2003). Moreover, TMNR host an assemblage of sedentary breeding or migrant birds linked to mature forests and agro-forest landscapes, including species of local ecological interest and conservation concern (Brunelli et al., 2011): among them, Accipiter nisus (Linnaeus, 1758)(see Battisti, 2011), Otus scops (Linnaeus, 1758), Cuculus canorus Linnaeus, 1758, Upupa epops Linnaeus, 1758, Picus viridis Linnaeus, 1758, Dendrocopos major (Linnaeus, 1758), Oriolus oriolus (Linnaeus, 1758). All these species are relatively very localized and with "patchy" populations inside the metropolitan area of Rome (Battisti \& Fraticelli, 2005). Salvati \& Manganaro (1999) locally showed a high linear density of Dedrocopos major in the Torretta Massimi Quercus suber oak wood and in the Infernaccio mixed oak wood when compared to other sites of Latium.

Among mammals, TMNR hosts mammal species that are very localized in Rome metropolitan area as Muscardinus avellanarius (Linnaeus, 1758), Sorex samniticus Altobello, 1926 and Meles meles (Linnaeus, 1758)(Zapparoli et al., 2004).

Muscardinus avellanarius is a rodent that locally has been observed, directly, both in winter and in breeding period with individuals and nests. Between 1997 and 2004 inside the Infernaccio, and Sughereta Somaini oak wood fragments, we obtained evidences for 12 nests located on Clematis vitalba, Rosa semper- virens, Rubia peregrina, Asparagus sp., Cornus sp., Ulmus sp., Rubus sp., Smilax aspera. Locally, this species was also preyed by Tyto alba (Celauro \& Battisti, 2006). However, this small rodent may occur in TMNR probably with small-sized sub-populations, highly vulnerable for the isolation of the remnant oak wood fragments embedded in a largely urbanized matrix (metropolitan Rome area). Further research focused on this fragmentation-sensitive species (e.g., Bright et al., 1994; Bright \& Morris, 1994; Bright \& Morris, 1996 and the reviews in Mortelliti et al., 2010 and Spinozzi et al., 2012) are necessary to verify if these small populations are viable and if they are spatially structured as a meta-population. Among terrestrial mammals (excluding Chiroptera), this species represent the highest local conservation priority.

Sorex samniticus, although largely diffused in central Italy and in the 'Campagna Romana' (Amori et al., 2009) is here present with the only known populations included in the suburban metropolitan area (Zapparoli et $a l ., 2004)$. This species is linked to forest habitats and shows a sensitivity to forest fragmentation and isolation (e.g., Mortelliti et al. 2007; review in Mortelliti et al., 2010).

TMNR is the only nature reserve sited in Rome that include Meles meles among mammals. The badger is a moderately fragmentation-sensitive species (van de Zande et al., 2007; Mortelliti et al., 2010) and there are field evidences that an extensive road network may be perceived as barrier to dispersal (e.g., Clarke et al., 1998; Van der Zande et al., 2007; Battisti et al., 2012). The first sighting of this species in TMNR was obtained by road killing of an individual and probably this is locally the main threat acting on this species and on others, here commonly occurring, as Erinaceus europaeus Linnaeus, 1758 and Vulpes vulpes (Linnaeus, 1758). The only available record of Martes foina (Erxleben, 1777) (2011, pers. obs.) should be confirmed and has not been included in checklist.

Analogously to mustelids, represented by only one species, research on bats (Chiroptera) should be implemented for this area because the only data available (four species; Amori et al., 2009) may represent an underestimation.

As highlighted for other highly fragmented areas of the Campagna Romana (e.g., Cornicolani hilly area; Crucitti et al., 2013), further research should better focused on the local status of the species of conservation concern in terms of density, dynamics, and spatial distribution in wood patches and mosaics of TMNR, verifying the viability of their remnant populations (Gippoliti \& Amori, 2006): e.g., among mammals, for Muscardinus avellanarius (Linnaeus, 1758) and Sorex samniticus Altobello, 1926; among amphibians, for Hyla intermedia Boulenger, 1882 and Bufo lineatus Ninni, 1879. Moreover, also study at community level should be promoted (e.g., breeding bird structure of assemblages in different habitat types), also considering the role of anthropogenic disturbances as factor of change and species turnover of these remnant "relaxed" communities. 
Tab. 2 - Check list of birds (Aves) occurring in the "Tenuta dei Massimi" nature reserve (Rome, central Italy). We reported the species conservation concern at European (Dir.: Annex 1, "Birds" 79/409/CEE and 147/2009/CE Directives; Calvario et al., 2008) and Italian scale (Italian red list (LIPU and WWF, 1999: EX: Extinct; EN: Endangered; VU: Vulnerable; LR: Lower risk; DD: Data deficient) and species phenology at regional scale (Brunelli and Fraticelli, 2010: S: Sedentary; B: Breeding. M: Migratory; reg: regular; irr: irregular; W: Wintering; E: Non-breeding summer visitor). In the column 'breeding' we reported the possible or confirmed breeding in TMNR as certain (C), probable (P) and eventual (E). Note: (1): species breeding in Rome urban area with vagrant individuals observed in TMNR.

\begin{tabular}{|c|c|c|c|c|}
\hline Order/FAMILY/species & Regional phenology & Breeding & "Bird” Dir. & Italian Red list \\
\hline \multicolumn{5}{|l|}{ Anseriformes } \\
\hline \multicolumn{5}{|l|}{ ANATIDAE } \\
\hline Anas platyrhynchos Linnaeus, 1758 & Mreg, W, SB & $\mathrm{P}$ & & \\
\hline \multicolumn{5}{|l|}{ Galliformes } \\
\hline \multicolumn{5}{|l|}{ PHASIANIDAE } \\
\hline Coturnix coturnix (Linnaeus, 1758) & Mreg, B, Wirr & $\mathrm{P}$ & & LR \\
\hline Phasianus colchicus Linnaeus, 1758 & SB & $\mathrm{C}$ & & \\
\hline \multicolumn{5}{|l|}{ Pelecaniformes } \\
\hline \multicolumn{5}{|l|}{ PHALACROCORACIDAE } \\
\hline Phalacrocorax carbo (Linnaeus, 1758) & Mreg, W, SB, E & & & EN \\
\hline \multicolumn{5}{|l|}{ Ciconiiformes } \\
\hline \multicolumn{5}{|l|}{ ARDEIDAE } \\
\hline Bubulcus ibis (Linnaeus, 1758) & Mreg, W, E, Birr & & & VU \\
\hline Ardea cinerea Linnaeus, 1758 & Mreg, W, E, Birr & & & LR \\
\hline Ardea purpurea Linnaeus, 1766 & Mreg, B & & $\mathrm{X}$ & LR \\
\hline \multicolumn{5}{|l|}{ Falconiformes } \\
\hline \multicolumn{5}{|l|}{ ACCIPITRIDAE } \\
\hline Pernis apivorus (Linnaeus, 1758) & Mreg, B, W irr & & $\mathrm{X}$ & VU \\
\hline Milvus migrans (Boddaert, 1783) & Mreg, B, Wirr & $\mathrm{C}$ & $X$ & VU \\
\hline Circaeuts gallicus (J. F. Gmelin, 1788) & Mreg, B, W irr & & $\mathrm{X}$ & EN \\
\hline Circus aeruginosus (Linnaeus, 1758) & Mreg, W, E & & $\mathrm{X}$ & EN \\
\hline Circus cyaneus (Linnaeus, 1766) & Mreg, W & & $\mathrm{X}$ & EX \\
\hline Accipiter nisus (Linnaeus, 1758) & SB, Mreg, W & & & \\
\hline Buteo buteo (Linnaeus, 1758) & SB, Mreg, W & $\mathrm{P}$ & & \\
\hline \multicolumn{5}{|l|}{ FALCONIDAE } \\
\hline Falco tinnunculus Linnaeus, 1758 & SB, Mreg, W & $\mathrm{C}$ & & \\
\hline Falco columbarius Linnaeus, 1758 & Mreg, W & & $\mathrm{X}$ & \\
\hline Falco eleonorae Gené, 1839 & Mreg, E & & $\mathrm{X}$ & VU \\
\hline Falco subbuteo Linnaeus, 1758 & Mreg, B & & & VU \\
\hline Falco peregrinus Tunstall, 1771 & SB, Mreg, W & $(1)$ & $\mathrm{X}$ & $\mathrm{VU}$ \\
\hline \multicolumn{5}{|l|}{ Gruiformes } \\
\hline \multicolumn{5}{|l|}{ RALLIDAE } \\
\hline Rallus aquaticus Linnaeus, 1758 & SB, Mreg, W & $\mathrm{E}$ & & DD \\
\hline Gallinula chloropus (Linnaeus, 1758) & SB, Mreg, W & $\mathrm{P}$ & & \\
\hline
\end{tabular}




\begin{tabular}{|c|c|c|c|c|}
\hline Order/FAMILY/species & Regional phenology & Breeding & "Bird" Dir. & Italian Red list \\
\hline \multicolumn{5}{|l|}{ Charadriiformes } \\
\hline \multicolumn{5}{|l|}{ CHARADRIIDAE } \\
\hline Vanellus vanellus (Linnaeus, 1758) & Mreg, W, E & & & \\
\hline \multicolumn{5}{|l|}{ SCOLOPACIDAE } \\
\hline Gallinago gallinago (Linnaeus, 1758) & Mreg, W & & & \\
\hline Scolopax rusticola Linnaeus, 1758 & Mreg, W & & & \\
\hline Actitis hypoleucos (Linnaeus, 1758) & Mreg, W, E, Birr & & & VU \\
\hline \multicolumn{5}{|l|}{ LARIDAE } \\
\hline Chroicocephalus ridibundus (Linnaeus, 1766) & Mreg, W, E & & & VU \\
\hline Larus michaellis Naumann, 1840 & Mreg, SB & & & \\
\hline \multicolumn{5}{|l|}{ Psittaciformes } \\
\hline \multicolumn{5}{|l|}{ PSITTACIDAE } \\
\hline Psittacula krameri (Scopoli, 1769) & SB & $\mathrm{C}$ & & \\
\hline Myiopsitta monachus (Boddaert, 1783) & SB & $\mathrm{P}$ & & \\
\hline \multicolumn{5}{|l|}{ Columbiformes } \\
\hline \multicolumn{5}{|l|}{ COLUMBIDAE } \\
\hline Columba livia J. F. Gmelin, 1789 f. domestica & SB & $\mathrm{C}$ & & \\
\hline Columba palumbus Linnaeus, 1758 & Mreg, W, SB & & & \\
\hline Streptopelia decaocto (Frivaldszky, 1838) & SB & $\mathrm{C}$ & & \\
\hline Streptopelia turtur (Linnaeus, 1758) & Mreg, B & $\mathrm{C}$ & & \\
\hline \multicolumn{5}{|l|}{ Cuculiformes } \\
\hline \multicolumn{5}{|l|}{ CUCULIDAE } \\
\hline Cuculus canorus Linnaeus, 1758 & Mreg, B & $\mathrm{C}$ & & \\
\hline \multicolumn{5}{|l|}{ Strigiformes } \\
\hline \multicolumn{5}{|l|}{ TYTONIDAE } \\
\hline Tyto alba (Scopoli, 1769) & SB, Mirr & $\mathrm{C}$ & & LR \\
\hline \multicolumn{5}{|l|}{ STRIGIDAE } \\
\hline Otus scops (Linnaeus, 1758) & Mreg, B, Wirr & $\mathrm{E}$ & & LR \\
\hline Athene noctua (Scopoli, 1769) & SB, Mirr & $\mathrm{C}$ & & \\
\hline Strix aluco Linnaeus, 1758 & SB, Mirr & $\mathrm{C}$ & & \\
\hline Asio otus (Linnaeus, 1758) & Mreg, W, SB & & & LR \\
\hline \multicolumn{5}{|l|}{ Caprimulgiformes } \\
\hline \multicolumn{5}{|l|}{ CAPRIMULGIDAE } \\
\hline Caprimulgus europaeus Linnaeus, 1758 & Mreg, B & & $\mathrm{X}$ & DD \\
\hline \multicolumn{5}{|l|}{ Apodiformes } \\
\hline \multicolumn{5}{|l|}{ APODIDAE } \\
\hline Apus apus (Linnaeus, 1758) & Mreg, B, Wirr & $\mathrm{C}$ & & \\
\hline \multicolumn{5}{|l|}{ Coraciiformes } \\
\hline \multicolumn{5}{|l|}{ ALCEDINIDAE } \\
\hline Alcedo atthis (Linnaeus, 1758) & SB, Mreg, W & & $\mathrm{X}$ & VU \\
\hline MEROPIDAE & & & & \\
\hline
\end{tabular}




\begin{tabular}{|c|c|c|c|c|}
\hline Order/FAMILY/species & Regional phenology & Breeding & "Bird" Dir. & Italian Red list \\
\hline Merops apiaster Linnaeus, 1758 & Mreg, B & $\mathrm{C}$ & & \\
\hline \multicolumn{5}{|l|}{ UPUPIDAE } \\
\hline Upupa epops Linnaeus, 1758 & Mreg, B, Wirr & $\mathrm{P}$ & & \\
\hline \multicolumn{5}{|l|}{ Piciformes } \\
\hline \multicolumn{5}{|l|}{ PICIDAE } \\
\hline Jynx torquilla Linnaeus, 1758 & Mreg, B, W & $\mathrm{P}$ & & \\
\hline Picus viridis Linnaeus, 1758 & SB, Mirr & $\mathrm{C}$ & & LR \\
\hline Dendrocopos major (Linnaeus, 1758) & SB, Mirr & $\mathrm{C}$ & & \\
\hline \multicolumn{5}{|l|}{ Passeriformes } \\
\hline \multicolumn{5}{|l|}{ ALAUDIDAE } \\
\hline Calandrella brachydactyla (Leisler, 1814) & Mreg, B & $\mathrm{P}$ & $\mathrm{X}$ & DD \\
\hline Galerida cristata (Linnaeus, 1758) & SB, Mreg, W & $\mathrm{C}$ & & \\
\hline Alauda arvensis Linnaeus 1758 & SB, Mreg, W & $\mathrm{C}$ & & \\
\hline \multicolumn{5}{|l|}{ HIRUNDINIDAE } \\
\hline Hirundo rustica Linnaeus, 1758 & Mreg, B, Wirr & $\mathrm{C}$ & & \\
\hline Delichon urbicum (Linnaeus, 1758) & Mreg, B, Wirr & $\mathrm{C}$ & & \\
\hline \multicolumn{5}{|l|}{ MOTACILLIDAE } \\
\hline Anthus pratensis (Linnaeus, 1758) & Mreg, W & & & \\
\hline Motacilla cinerea Tunstall, 1771 & Mreg, SB, W & & & \\
\hline Motacilla alba Linnaeus, 1758 & SB, Mreg, W & $\mathrm{C}$ & & \\
\hline \multicolumn{5}{|l|}{ TROGLODYTIDAE } \\
\hline Troglodytes troglodytes (Linnaeus, 1758) & SB, Mreg, W & $\mathrm{C}$ & & \\
\hline \multicolumn{5}{|l|}{ PRUNELLIDAE } \\
\hline Prunella modularis (Linnaeus, 1758) & Mreg, W, SB & & & \\
\hline \multicolumn{5}{|l|}{ TURDIDAE } \\
\hline Erithacus rubecula (Linnaeus, 1758) & Mreg, W, SB & $\mathrm{P}$ & & \\
\hline Luscinia megarhynchos C.L. Brehm, 1831 & Mreg, B, Wirr & $\mathrm{C}$ & & \\
\hline Phoenicurus ochruros (S.G. Gmelin, 1789) & SB, Mreg, W & & & \\
\hline Saxicola rubetra (Linnaeus, 1758) & Mreg, Wirr & & & \\
\hline Saxicola torquatus (Linnaeus, 1758) & SB, Mreg, W & $\mathrm{C}$ & & \\
\hline Monticola solitarius (Linnaeus, 1758) & SB, Mreg & $\mathrm{P}$ & & \\
\hline Turdus merula Linnaeus, 1758 & SB, Mreg, W & $\mathrm{C}$ & & \\
\hline Turdus philomelos C.L. Brehm, 1831 & Mreg, W, SB & & & \\
\hline Turdus iliacus Linnaeus, 1766 & Mreg, W & & & \\
\hline \multicolumn{5}{|l|}{ SYLVIIDAE } \\
\hline Cettia cetti (Temminck, 1820) & SB,Mreg, W & $\mathrm{C}$ & & \\
\hline Cisticola juncidis (Refinesque, 1810) & SB, Mirr, W & $\mathrm{C}$ & & \\
\hline Hippolais polyglotta (Vieillot, 1817) & Mreg, B & $\mathrm{P}$ & & \\
\hline Sylvia atricapilla (Linnaeus, 1758) & SB, Mreg, W & $\mathrm{C}$ & & \\
\hline Sylvia cantillans (Pallas, 1764) & Mreg, B & $\mathrm{C}$ & & \\
\hline Sylvia melanocephala (J.F. Gmelin, 1789) & SB, Mreg, W & $\mathrm{C}$ & & \\
\hline
\end{tabular}




\begin{tabular}{|c|c|c|c|c|}
\hline Order/FAMILY/species & Regional phenology & Breeding & "Bird" Dir. & Italian Red list \\
\hline Phylloscopus collybita (Vieillot, 1817) & Mreg, SB, W & $\mathrm{E}$ & & \\
\hline Phylloscopus trochilus (Linnaeus, 1758) & Mreg & & & \\
\hline Regulus regulus (Linnaeus, 1758) & Mreg, SB, W & & & \\
\hline Regulus ignicapilla Temminck, 1820 & Mreg, SB, W & $\mathrm{C}$ & & \\
\hline \multicolumn{5}{|l|}{ MUSCICAPIDAE } \\
\hline Muscicapa striata (Pallas, 1764) & Mreg, SB & $\mathrm{P}$ & & \\
\hline Ficedula albicollis (Temminck, 1815) & Mreg, B & & $\mathrm{X}$ & \\
\hline \multicolumn{5}{|l|}{ AEGITHALIDAE } \\
\hline Aegithalos caudatus (Linnaeus, 1758) & SB, Mreg, W & $\mathrm{C}$ & & \\
\hline \multicolumn{5}{|l|}{ PARIDAE } \\
\hline Cyanistes caeruleus (Linnaeus, 1758) & SB, Mirr, W & $\mathrm{C}$ & & \\
\hline Parus major Linnaeus, 1758 & SB,Mirr, W & $\mathrm{C}$ & & \\
\hline \multicolumn{5}{|l|}{ CERTHIIDAE } \\
\hline Certhia brachydactyla C.L. Brehm, 1820 & SB, Mirr & $\mathrm{C}$ & & \\
\hline \multicolumn{5}{|l|}{ REMIZIDAE } \\
\hline Remiz pendulinus (Linnaeus, 1758) & SB, Mreg, W & $\mathrm{C}$ & & \\
\hline \multicolumn{5}{|l|}{ ORIOLIDAE } \\
\hline Oriolus oriolus (Linnaeus, 1758) & Mreg, B & $\mathrm{C}$ & & \\
\hline \multicolumn{5}{|l|}{ LANIIDAE } \\
\hline Lanius collurio Linnaeus, 1758 & Mreg, B, Wirr & $\mathrm{P}$ & $\mathrm{X}$ & \\
\hline Lanius senator Linnaeus, 1758 & Mreg, B & & & VU \\
\hline \multicolumn{5}{|l|}{ CORVIDAE } \\
\hline Garrulus glandarius (Linnaeus, 1758) & SB, Mirr & & & \\
\hline Pica pica (Linnaeus, 1758) & SB & $\mathrm{P}$ & & \\
\hline Corvus monedula Linnaeus, 1758 & SB, Mirr & (1) & & \\
\hline Corvus cornix Linnaeus, 1758 & SB, Mirr & $\mathrm{C}$ & & \\
\hline \multicolumn{5}{|l|}{ STURNIDAE } \\
\hline Sturnus vulgaris Linnaeus, 1758 & Mreg, W, SB & $\mathrm{C}$ & & \\
\hline \multicolumn{5}{|l|}{ PASSERIDAE } \\
\hline Passer domesticus (Linnaeus, 1758) & SB & $\mathrm{C}$ & & \\
\hline Passer montanus (Linnaeus, 1758) & SB, Mreg & $\mathrm{C}$ & & \\
\hline \multicolumn{5}{|l|}{ FRINGILLIDAE } \\
\hline Fringilla coelebs Linnaeus, 1758 & SB, Mreg, W & $\mathrm{C}$ & & \\
\hline Serinus serinus (Linnaeus, 1766) & SB, Mreg, W & $\mathrm{C}$ & & \\
\hline Carduelis chloris (Linnaeus, 1758) & SB, Mreg, W & $\mathrm{C}$ & & \\
\hline Carduelis carduelis (Linnaeus, 1758) & SB, Mreg, W & $\mathrm{C}$ & & \\
\hline Carduelis spinus (Linnaeus, 1758) & Mreg, W, Eirr & & & \\
\hline \multicolumn{5}{|l|}{ EMBERIZIDAE } \\
\hline Emberiza cirlus Linnaeus, 1766 & SB, Mreg, W & $\mathrm{C}$ & & \\
\hline Emberiza cia Linnaeus, 1766 & SB, Mreg, W & & & \\
\hline Emberiza calandra Linnaeus, 1758 & SB, Mreg, W & $\mathrm{C}$ & & \\
\hline
\end{tabular}


Tab. 3 - Check list of mammals (Mammalia) occurring in the "Tenuta dei Massimi" nature reserve (Rome, central Italy). The inclusion in the "Habitat" Dir.: Annex IV of "Habitat" 92/43/CEE Directive (Calvario et al., 2008; Amori et al., 2009) and in the Italian red list are reported (Bulgarini et al., 1998). VU: vulnerable; LR: lower risk; DD: data deficient.

\begin{tabular}{|c|c|c|}
\hline Order/FAMILY/species & $\begin{array}{l}\text { "Habitat" } \\
\text { Dir. }\end{array}$ & $\begin{array}{l}\text { Italian } \\
\text { Red list }\end{array}$ \\
\hline \multicolumn{3}{|l|}{ Erinaceomorpha } \\
\hline \multicolumn{3}{|l|}{ ERINACEIDAE } \\
\hline \multicolumn{3}{|l|}{ Erinaceus europaeus Linnaeus, 1758} \\
\hline \multicolumn{3}{|l|}{ TALPIDAE } \\
\hline \multicolumn{3}{|l|}{ Talpa romana Thomas, 1902} \\
\hline \multicolumn{3}{|l|}{ Soricomorpha } \\
\hline \multicolumn{3}{|l|}{ SORICIDAE } \\
\hline Sorex samniticus Altobello, 1926 & & DD \\
\hline \multicolumn{3}{|l|}{ Suncus etruscus (Savi, 1822) } \\
\hline \multicolumn{3}{|l|}{ Crocidura suaveolens (Pallas,1811) } \\
\hline \multicolumn{3}{|l|}{ Crocidura leucodon (Hermann, 1780) } \\
\hline \multicolumn{3}{|l|}{ Chiroptera } \\
\hline \multicolumn{3}{|l|}{ VESPERTILIONIDAE } \\
\hline Pipistrellus kuhlii (Kuhl, 1817) & IV & LR \\
\hline $\begin{array}{l}\text { Pipistrellus nathusii (Keyserling e } \\
\text { Blasius, 1839) }\end{array}$ & IV & VU \\
\hline Hypsugo savii (Bonaparte, 1837) & IV & LR \\
\hline \multicolumn{3}{|l|}{ MOLOSSIDAE } \\
\hline Tadarida teniotis (Rafinesque, 1814) & IV & LR \\
\hline \multicolumn{3}{|l|}{ Lagomorpha } \\
\hline \multicolumn{3}{|l|}{ LEPORIDAE } \\
\hline \multicolumn{3}{|l|}{ Lepus europaeus Pallas, 1778} \\
\hline \multicolumn{3}{|l|}{ Rodentia } \\
\hline \multicolumn{3}{|l|}{ HYSTRICIDAE } \\
\hline Hystrix cristata Linnaeus, 1758 & IV & \\
\hline \multicolumn{3}{|l|}{ MYOCASTORIDAE } \\
\hline \multicolumn{3}{|l|}{ Myocastor coypus (Molina, 1782) } \\
\hline \multicolumn{3}{|l|}{ GLIRIDAE } \\
\hline $\begin{array}{l}\text { Muscardinus avellanarius (Linnaeus, } \\
\text { 1758) }\end{array}$ & IV & \\
\hline \multicolumn{3}{|l|}{$\begin{array}{l}\text { 1758) } \\
\text { CRICETIDAE }\end{array}$} \\
\hline \multicolumn{3}{|l|}{$\begin{array}{l}\text { Microtus (Terricola) savii (De Sélys } \\
\text { Longchamps, 1838) }\end{array}$} \\
\hline \multicolumn{3}{|l|}{ MURIDAE } \\
\hline \multicolumn{3}{|l|}{ Rattus norvegicus (Berkenhout, 1769) } \\
\hline \multicolumn{3}{|l|}{ Rattus rattus (Linnaeus, 1758) } \\
\hline \multicolumn{3}{|l|}{ Apodemus sylvaticus (Linnaeus, 1758) } \\
\hline Mus musculus Linnaeus, 1758 & & \\
\hline Carnivora & & \\
\hline CANIDAE & & \\
\hline Vulpes vulpes (Linnaeus, 1758) & & \\
\hline MUSTELIDAE & & \\
\hline Meles meles (Linnaeus, 1758) & & \\
\hline
\end{tabular}

\section{Acknowledgements}

We would acknowledge all the colleagues that have allowed this review with original data from field sampling (1991-2012 period): G. Amori, F.M. Angelici, M.A. Bologna, F. Borlenghi, V. Botticelli, A. Buscemi, E. Calvario, L. Cancellieri, E. Calvario, M. Caporioni, A. Cardillo, G. M. Carpaneto, R. Caruso, J.G. Cecere, M. Cento, G. Ciccotosto, L. Contoli, G. Ferrero, A. Folletto, F. Foschi (Ente RomaNatura), F. Fraticelli, P. Giampaoletti, P. Harris, S. Hueting, L. Ianniello, R. Lippolis, E. Lorenzetti, R. Maggini, C. Marangoni, C. Mari, P. Menichetti, R. Molajoli, A. Monteforte, P. Monti ("Allocco" Project - Ente RomaNatura), G. Montinaro, S. Morandi, G. Nobili, L. Nottari, D. Ortenzi, G. Pallara, U. Pessolano, F. Petrassi, F. Petrozzi, S. Risa, E. Savo, S. Sciré, C. Teofili, M. Tomassetti, C. Tomei, M. Trotta, P. Tuccinardi, M. Valori, A. Venchi, A. Zocchi. I would acknowledge also A. Cardillo, M. Cento, F. Fraticelli, $\mathrm{S}$. Hueting for the full availability of data related to the project named "Atlante degli uccelli in inverno a Roma: 2007-2011" Project; R. Molajoli, M.Brunelli (Ornitho e GroB!); M.A. Bologna and M. Pitzalis (Alien species data bank - University of Rome III). Spartaco Gippoliti have critically reviewed a first draft of the manuscript. Thanks also to Giovanni Amori, Marco A. Bologna, Massimo Brunelli and Vincenzo Ferri for the further review of the check-lists. Two anonymous reviewers have suggested further comments that have improved this work.

\section{REFERENCES}

Amori G., Battisti C. \& De Felici S., 2009 - I Mammiferi della Provincia di Roma. Dallo stato delle conoscenze alla gestione e conservazione delle specie. Provincia di Roma, Assessorato alle politiche dell'agricoltura. Stilgrafica, Roma.

Amori G., Contoli L. \& Nappi A., 2008 - Mammalia II: Erinaceomorpha, Soricomorpha, Lagomorpha, Rodentia. Vol. XLIV, Fauna d'Italia. Edizioni Calderini, Il Sole-24 Ore, Milano.

Anzalone B., 1986 - La flora vascolare spontanea delle rive del Tevere e i suoi affluenti entro Roma. Annali di Botanica, Roma, 44 (suppl. 4): 1-46.

Arnoldus-Huyzendveld A., 2003 - I suoli di Roma. Comune di Roma, Dip. X, Roma.

Battisti C. (ed.), 2001 - Il Nibbio bruno Milvus migrans nella Riserva naturale Tenuta dei Massimi. Roma. WWF Lazio, Ente RomaNatura, Roma.

Battisti C., 2011 - A mobbing event of Barn swallows Hirundo rustica on Sparrowhawk Accipiter nisus in Rome (Central Italy). Alula, 18: 134-136.

Battisti C., Amori G., De Felici S., Luiselli L. \& Zapparoli M., 2012 - Mammal road-killing from a Mediterranean area in central Italy: evidence from an atlas dataset. Accademia Nazionale dei Lincei, Rendiconti Scienze Fisiche e Naturali, 23: 217-223.

Battisti C., Bottinelli V., Caruso R., Ferrero G., Mari C., Parrella M., Pallara G., Tomassetti M. \& Zocchi A., 2001 - Il Nibbio bruno (Milvus migrans) a Roma: dati dalla Riserva naturale "Tenuta dei Massimi”. Alula, 8: 29-33. 
Battisti C., Calvario E., Pacini A., Teofili C., Venchi A. \& Zocchi A., 1998b - L'Infernaccio e la Tenuta Massimi: un'area a elevata diversità ambientale all'interno del G.R.A. di Roma. In: Bologna M.A., Carpaneto G.M., Cignini B. (eds.), 1998. Atti del $1^{\circ}$ Conv. Naz. Fauna Urbana, Roma, 12 aprile 1997. Fratelli Palombi Editori: $277-279$.

Battisti C. \& Cignini B., 1997 - Nibbio bruno Milvis migrans. In: Atlante degli uccelli nidificanti a Roma. Cignini B., Zapparoli M. (eds.). Fratelli Palombi Editori, Roma: 40.

Battisti C. \& Fraticelli F., 2005 - Avifauna forestale e frammentazione ambientale in un'area urbana: un contributo alla individuazione di specie sensibili a Roma. Atti Convegni Lincei, 218: 519-527.

Battisti C. \& Gippoliti S., 2004 - Conservation in the urban/countryside interface: a cautionary note from Italy. Conservation Biology, 18: 581-583.

Battisti C., Mari C., Tomassetti M. \& Zocchi A., 2003 - La colonia suburbana di Nibbio bruno, Milvus migrans, a Roma: attività riproduttiva e roosting premigratorio. Rivista Italiana di Ornitologia, 73: 97-103.

Battisti C., Marini L. \& Villetti G., 1998a - Evoluzione storica di Nibbio reale (Milvus milvus) e Nibbio bruno (Milvus migrans) nel settore sud-orientale della città di Roma e fattori antropici correlati: prime osservazioni. Bologna M.A., Carpaneto G.M., Cignini B.(eds.), 1998. Atti del $1^{\circ}$ Conv. Naz. Fauna Urbana, Roma, 12 aprile 1997. Fratelli Palombi Editori: 171-174.

Battisti C. \& Zapparoli M., 2011 - Sulla nomenclatura delle popolazioni urbane di Columba livia J.F. Gmelin, 1789: una revisione critica della letteratura in Italia. Avocetta, 35: 23-29.

Battisti C. \& Zocchi A., 2004 - Nesting habitat structure of the Black Kite, Milvus migrans, in a suburban area (Rome, Central Italy). Rivista Italiana di Ornitologia, 74: 97-106.

Battisti C. \& Zocchi A., 2010 - Cattle egret, Bubulcus ibis, flock wintering in an urbanized landscape (Rome, Central Italy). Rivista Italiana di Ornitologia, 79: 137138.

Bellotti P. Ciocchini U., Cipriani N. \& Milli S., 1993 - I sistemi deposizionali nei sedimenti clastici Pleistocenici affioranti nei dintorni di Ponte Galeria (sud-ovest di Roma). Bollettino della Società Geologica Italiana, 112: 923-941.

Benassi G., Battisti C., Luiselli L. \& Boitani L., 2009 Area-sensitivity of three reed bed bird species breeding in Mediterranean marshland fragments. Wetlands Ecology and Management, 17: 555-564.

Blasi C., 2001 - Flora, vegetazione ed ecologia del paesaggio delle aree protette di RomaNatura. Informatore Botanico Italiano, 33, suppl. 1: 14-18.

Boitani L., Lovari S. \& Vigna Taglianti A., 2003 - Mammalia III: Carnivora - Arctiodactyla. Vol. XXXVIII, Fauna d'Italia. Edizioni Calderini, Il Sole-24 Ore, Milano.

Bologna M.A., Calvario E. \& Sarrocco S., 2001 - Le ricerche faunistiche nelle aree protette di Roma Natura. Informatore Botanico Italiano, 33, suppl. 1: 1922.
Bologna M.A., Capula M. \& Carpaneto G.M. (eds.), 2000 Anfibi e rettili del Lazio. Fratelli Palombi editori, Roma.

Bologna M.A., Capula M., Carpaneto G.M., Cignini B., Marangoni C., Venchi A. \& Zapparoli M., 2003 - Anfibi e rettili a Roma. Atlante e guida delle specie presenti in città. Comune di Roma, Assessorato Ambiente- Assessorato Cultura, Stilgrafica, Roma.

Bologna M.A., Salvi D. \& Pitzalis M. (eds.), 2007 - Atlante degli anfibi e rettili della Provincia di Roma. Provincia di Roma, Assessorato alle Politiche Agricole e Ambientali, Università degli studi Roma Tre, Roma.

Borlenghi F., 1996 - Nidificazione di Nibbio bruno Milvus migrans all'interno del raccordo anulare di Roma. Alula, 3: 122-123.

Borlenghi F., 2013 - Osservazioni di rapaci in periodo estivo nella Riserva naturale "Tenuta dei Massimi" all'interno del Grande Raccordo Anulare di Roma. Alula, 20: 121-122.

Bright P.W., Mitchell P. \& Morris P.A., 1994 - Dormouse distribution - survey techniques, insular ecology and selection of sites for conservation. Journal of Applied Ecology, 31: 329-339.

Bright P.W. \& Morris P.A., 1994 - A review of the Dormouse (Muscardinus avellanarius) in England and a conservation programme to safeguard its future. Hystrix, 6: 295-302.

Bright P.W. \& Morris P.A., 1996 - Why are Dormice rare? A case study in conservation biology. Mammal Review, 26: 157-187.

Brunelli M. \& Fraticelli F., 2010 - Check-list degli uccelli del Lazio aggiornata al dicembre 2009. Rivista Italiana di Ornitologia, 80: 3-20.

Brunelli M., Sarrocco S., Corbi F., Sorace A., Boano A., De Felici S., Guerrieri G., Meschini A. \& Roma S., 2011 - Nuovo Atlante degli Uccelli Nidificanti nel Lazio. Edizioni ARP (Agenzia Regionale Parchi), Roma.

Bulgarini F., Calvario E., Fraticelli F., Petretti F. \& Sarrocco S. (eds.), 1998 - Libro Rosso degli Animali d'Italia. Vertebrati. WWF Italia, Roma.

Buscemi A., Cignini B. \& Contoli L., 1995 - Aspetti quali-quantitativi delle zoocenosi ad uccelli e mammiferi nell'ambiente urbano di Roma. Atti S.IT.E., 16: 445448.

Calvario E., Brunelli M, Sarrocco S., Bulgarini F., Fraticelli F. \& Sorace A., 2011 - Lista rossa degli uccelli nidificanti nel Lazio. In: Nuovo Atlante degli Uccelli Nidificanti nel Lazio. Brunelli M., Sarrocco S., Corbi F., Sorace A., Boano A., De Felici S., Guerrieri G., Meschini A., Roma S. (eds.). Edizioni ARP (Agenzia Regionale Parchi), Roma: 427-435.

Calvario E., Sebasti S., Copiz R., Salomone F., Brunelli M., Tallone G. \& Blasi C., 2008 - Habitat e specie di interesse comunitario nel Lazio. Edizioni ARP (Agenzia Regionale Parchi), Roma.

Carbone F. \& Frassineti M., 2001 - I parchi naturali di Roma. Ente Roma Natura.

Castaldi A. \& Guerrieri G., 2009 - Uso trofico dell'habitat e preferenze ambientali del Nibbio bruno Milvus migrans nell'hinterland romano (Lazio, Italia centrale). Gli Uccelli d'Italia, 34: 67-79. 
Celauro D. \& Battisti C., 2006 - Small mammal communities in a suburban agroforest landscape (Rome, Central Italy): faunal and ecological considerations using Tyto alba pellets. Aldrovandia, Bollettino del Museo Civico di Zoologia di Roma, 2: 55-60.

Celesti Grapow L., 1995 - Atlante della flora di Roma. La distribuzione delle piante spontanee come indicatore ambientale. Comune di Roma, Ufficio Tutela Ambiente. Argos edizioni, Roma.

Celesti Grapow L. \& Fanelli G., 1993 - the vanishing landscape of the Campagna Romana. Landscape and Urban Planning, 24: 69-76.

Cignini B. \& Zapparoli M. (eds.), 1996 - Atlante degli uccelli nidificanti a Roma. Fratelli Palombi Editore, Roma.

Cignini B. \& Zapparoli M., 1992 - Conservazione dell'avifauna ed ambiente urbano: considerazioni su alcune specie presenti nella città di Roma. Alula, 1: 111-114.

Clarke G.P., White P.C.L. \& Harris S., 1998 - Effects of roads on Badger Meles meles population in SouthWest England. Biological Conservation, 86: 117124.

Contoli L., 2002 - Aspetti evolutivi nella biodiversità e nell'insularità ecologica di Roma. Atti Conv. "Ecosistemi urbani”, Roma, 22-24 ottobre 2001. Atti Convegni Lincei, 182: 155-165.

Corti C., Capula M., Luiselli L., Razzetti E. \& Sindaco R., 2010 - Reptilia. Fauna d'Italia, vol. XLV. Edizioni Calderini, Il Sole-24 Ore, Milano.

Crucitti P., Amori G., Battisti C. \& Giardini M., 2013 Check-list degli Anfibi, Rettili, Uccelli, Mammiferi dell'area "arcipelago mentanese-cornicolano" (Campagna Romana, Lazio). Bollettino Museo Civico di Storia Naturale di Verona, Botanica Zoologia, 37: 2946.

De Giacomo U., Battisti C., Cecere J.C., Ricci S., Borlenghi F. \& Tinelli A., 2003 - La popolazione romana di Nibbio bruno (Milvus migrans): aspetti ecologici. In: Uccelli rapaci nel Lazio: status e distribuzione, strategie di conservazione. Corsetti L. (ed.). Atti del Convegno, Sperlonga, 13.12.2003. Ed. Belvedere, Latina: 95-124.

Downgiallo G., Testi A. \& Pesoli P., 1997 - Edaphic characteristics of Quercus suber woods in Latium. Rendiconti Accademia Nazionale dei Lincei, 8 (9): 249264.

Fanelli G., 2002 - Analisi fitosociologica dell'area metropolitana di Roma. Braun-Blanquetia, 27: 11-12.

Fanelli G. \& Bianco P.M. (eds.), 2007 - Memoria illustrativa della carta della vegetazione della Provincia di Roma. Provincia di Roma, Dip. VI. Governo del territorio, Serv. 3. Sistema Informativo Geografico, Roma.

Fanelli G. \& Celesti-Grapow L., 1994 - La flora del bacino del fosso della Magliana (Roma). Annali di Botani$c a$, Roma, 52 (suppl. 11): 83-114.

Fracasso G., Baccetti N. \& Serra L., 2009 - La lista CISO-COI degli Uccelli italiani. Parte prima: liste A, B e C. Avocetta, 33: 5-24.
Gippoliti S. \& Amori G., 2006 - Historical data on nonvolant mammals in Rome: what do they say about urban environment? Aldrovandia, Bollettino del Museo Civico di Zoologia di Roma, 2: 69-72.

Kottelat M. \& Freyhof J., 2007 - Handbook of European freshwater fishes. Cormol, Publications Kottelat, Switzerland and Freyhof, Germany.

LIPU \& WWF (eds.), 1999 - Nuova Lista Rossa degli uccelli nidificanti in Italia. Rivista Italiana di Ornitologia, 69: 3-43.

Marra F. \& Rosa C., 1995 - Stratigrafia e assetto geologico dell'area romana. Memorie descrittive della Carta Geologica d'Italia, 50: 49-112.

Montinaro G. \& Cancellieri L., 2002 - Le zone umide della Riserva naturale Tenuta dei Massimi, Roma. WWF Lazio, Roma.

Mortelliti A., Amori G., Capizzi D., Rondinini C. \& Boitani L., 2010 - Experimental design and taxonomic studies on European mammals: current status and future priorities. Mammal Review, 40: 125-154.

Mortelliti A., Amori G., Sammuri G. \& Boitani L., 2007 Factors affecting the distribution of Sorex samniticus, an endemic Italian shrew, in an heterogeneous landscape. Acta Theriologica, 52: 75-84.

Nibby A., 1848 - Analisi storico-topografica-antiquaria della carta dé dintorni di Roma. Tip. delle Belle arti, Roma.

Panuccio M., 2005 - Dati sulla presenza del Nibbio bruno Milvus migrans in due discariche di rifiuti urbani. Alula, 12: 189-192.

Panuccio M. \& Canale E., 2003 - Osservazione sui movimenti post-riproduttivi del Nibbio, Milvus migrans, nel Lazio, Italia centrale. Rivista Italiana di Ornitologia, 73: 180-182.

Pitzalis M., Marangoni C. \& Bologna M.A., 2005 - Analisi di processi di dispersione e colonizzazione tramite un GIS in tre specie di uccelli alloctoni nella fauna di Roma (Italia centrale). Alula, 12: 193-205.

Ronchetti G., 1968 - L'azione antianofelica dei pesci del genere Gambusia utilizzati per la lotta biologica contro la malaria. Natura, 58: 25-41.

Rotondi M., 1962 - Migratori alati. Le migrazioni degli uccelli in relazione all'esercizio della caccia e dell'uccellagione. La Rotografica romana, Roma.

Salvati L. \& Manganaro A., 1999 - Notes on the frequency of Great Spotted Woodpeckers Picoides major in some woods of Rome (Central Italy). Avocetta, Atti X Convegno italiano di Ornitologia: 191.

Sarrocco S., Battisti C., Brunelli M., Calvario E., Ianniello L., Sorace A., Teofili C., Trotta M., Visentin M. \& Bologna M.A., 2002 - L'avifauna delle aree naturali protette del Comune di Roma gestite dall'Ente Roma Natura. Alula, 9: 3-31.

Sarrocco S. \& Sorace A., 2011 - La ricchezza di specie delle aree protette e delle ZPS ed il loro valore ornitologico. In: Nuovo Atlante degli Uccelli Nidificanti nel Lazio. Brunelli M., Sarrocco S., Corbi F., Sorace A., Boano A., De Felici S., Guerrieri G., Meschini A., Roma S. (eds.). Edizioni ARP (Agenzia Regionale Parchi), Roma: 417-426. 
Sindaco R., Doria G., Razzetti E.\& Bernini F., 2006 Atlante degli anfibi e dei rettili d'Italia. Societas Herpetologica Italica, Edizioni Polistampa, Firenze.

Sorace A., 2001 - Value of wildlife of urban-agricultural parks: a case study from Rome urban area. Environmental Management, 28: 547-560.

Spinozzi F., Battisti C. \& Bologna MA., 2012 - Habitat fragmentation sensitivity in mammals: a target selection for landscape planning comparing two different approaches (bibliographic review and expert based). Rendiconti Accademia Nazionale dei Lincei, 23: 365373.

Stella E., Di Girolamo I., Dell'Uomo G. \& Rivosecchi L., 1984 - Osservazioni sulla distribuzione di Gambusia affinis (Baird e Girard, 1854) negli ambienti umidi naturali di Castel Porziano a 20 anni dalla loro immissione. Rivista di Idrobiologia, 23: 173-186.

Sutherland W.J., 2000 - The conservation handbook. Research, management and policy. Blackwell Science, Oxford, UK.

Testi A., Lucattini C., 1994 - Contribution to the syntaxonomic kowledge of Quercus suber woodlands of Latium. Rendiconti Accademia Nazionale dei Lincei, 5: 247-259.

Valenti M., 1964 - Impiego delle Gambusie per il controllo dell'anofelismo residuo a Castel Porziano (Roma). Rivista di Marialogia, 43: 50-62.
Van De Zande L., Van De Vliet M., Pertoldi C., Loeschcke V., Müskens G. \& Bijlsma R., 2007 - Genetic structure within and among regional populations of the Eurasian badger (Meles meles) from Denmark and the Netherlands. Journal of Zoology, London, 271: 302-309.

Venditti A., 1992 - La via Portuense e il suo territorio tra leggenda, storia e archeologia. Tipolitografia Trullo, Roma.

Ventriglia U., 2002 - Geologia del territorio del Comune di Roma. Provincia di Roma, Roma.

Volpes R., Buscemi A. \& Sorace A., 2004 - Dieta e presenza del Barbagianni (Tyto alba) in aree ad alta antropizzazione. In: Uccelli rapaci nel Lazio: status e distribuzione, strategie di conservazione. Corsetti L. (ed.). Atti del Convegno, Sperlonga, 13 dicembre 2003. Ed. Belvedere, Latina: 85-94.

Zapparoli M., Battisti C. \& Amori G., 2004 - Mammiferi come indicatori di frammentazione in aree urbane: il caso di Roma. Natura, 94: 63-71.

Zocchi A. \& Battisti C., 2004 - A proposal of a three-step method for rapid selection of potential Black Kite, Milvus migrans, nest trees during coppice management. Rivista Italiana di Ornitologia, 74: 139- 145.

Zocchi A., Lacroix L., Bianchi M. \& Battisti C., 2004 Characteristics of black kite Milvus migrans nest-trees in two Italian colonies. Avocetta, 28: 9-14. 